\title{
From exploration to operation: research developments in deep geothermal energy
}

\author{
Alexandra R. L. Kushnir ${ }^{1 *}$ and Markus Loewer ${ }^{2}$
}

*Correspondence:

alexandra.kushnir@gmail. com; akushnir@unistra.fr

${ }^{1}$ Université de Strasbourg, CNRS, IPGS, UMR 7516,

67000 Strasbourg, France Full list of author information is available at the end of the article

\section{Geosciences and a low-carbon economy}

By providing solutions for harnessing subsurface resources, the geosciences will emerge as a critical component of an efficient transition to a low-carbon economy. In particular, the potential for geothermal energy to supply clean base-load energy for heating and electricity worldwide is enormous. If developed appropriately, this georesource will play a decisive role in the global switch to renewable energies.

Geothermal energy exploitation has a strong history in Europe and is a key part of several municipal, national, and European low-carbon energy strategies. ${ }^{1}$ Through the deep geothermal pilot programme at Soultz-sous-Forêts (France) and the recent success of EGS ${ }^{2}$ sites at Rittershoffen (France) and Insheim (Germany), academic and industry leaders have demonstrated that geothermal energy generation is technically achievable even in low-permeability rocks. The economic viability of deep geothermal energy production in low-enthalpy regions has been verified by numerous geothermal heat plants in the Paris Basin (France), as well as the Molasse Basin (Southern Germany).

However, geothermal energy for heat and power production remains novel, as opposed to the norm. The complexity of the exploitation process requires the active participation of experts from a variety of fields. Indeed, key to the development of efficient and sustainable geothermal energy is the pursuit of new integrative approaches. Incorporating geothermal energy into the mainstream of energy production and use requires scientific and technical advances that reduce the cost and risk associated with resource exploration and extend the life of reservoirs and geothermal plants, while working with communities to assess and mitigate environmental risk.

\section{The European Geothermal Workshop}

The European Geothermal Workshop (EGW) is an annual gathering that brings together members of the European and international community to discuss interdisciplinary research aimed at advancing all stages of geothermal energy production, from exploration to operation. Started in 2013, this workshop has been organized by the Ecole

\footnotetext{
${ }^{1}$ Including the Strasbourg Eurometropole's Horizon 2030 energy plan, Munich's District-Heating Vision 2040, ETIPDG's Implementation Roadmap for Deep Geothermal, and the upcoming SET Deep Geothermal Implementation Plan.

2 Enhanced Geothermal System.
} 
et Observatoire des Sciences de la Terre (EOST) of the University of Strasbourg and the Karlsruhe Institute of Technology (KIT)'s Geothermal Chair, as a space for students and early career researchers to interact meaningfully with senior researchers and industry leaders. The EGW has grown significantly in recent years: The 6th EGW-held on 10-11 October 2018 in Strasbourg, France-was attended by 140 participants, from 17 countries. Additionally, in 2018, the European Energy Research Alliance (EERA) Geothermal Joint Programme ${ }^{3}$ joined the planning committee of this conference to highlight the importance of seven specific sub-programmes to the continued success of the geothermal energy sector in Europe; the workshop sessions were organized around these seven key topics (SP1-SP7). The EERA-Geothermal sub-programmes include:

\author{
SP1 Assessment of Geothermal Resources \\ SP2 Exploration of Geothermal Reservoirs \\ SP3 Constructing Geothermal Wells \\ SP4 Resource Development \\ SP5 Energy Conversion Systems \\ SP6 Operation of Geothermal Systems \\ SP7 Sustainability, Environment and Regulatory Framework \\ SP8 Computing and Data Management. ${ }^{4}$
}

\title{
From exploration to operation-research developments in deep geothermal energy
}

This EGW 2018 article collection brings together a selection of scientific contributions initially presented at the 6th European Geothermal Workshop. The contributions span the range of sub-programmes, including resource assessment, exploration and development and innovative plant operation. They draw on multiple approaches including field exploration, laboratory methods, and numerical modelling. Of the 11 contributions, nine showcase the work of early career researchers.

The deep geothermal potential of the remote Anticosti Island (Canada), located in the carbonate Anticosti sedimentary basin, is assessed by Gascuel et al. (2020). Despite a lack of detailed exploration owing to the remoteness of the location, the authors use sparse bottom-hole data to develop a 3D temperature model of the basement up to $40 \mathrm{~km}$ depth. The authors conclude that while geothermal electricity production at Anticosti Island is not currently feasible, the potential for direct geothermal heat use in the basin justifies further resource assessment and exploration.

To help refine heat flow models of the Upper Rhine Graben, Harlé et al. (2019) used experimental techniques to constrain the thermal conductivity of a series of sedimentary rocks under different temperature and saturation conditions. These data are used to calculate heat flow density at the Soultz-sous-Forêts and Rittershoffen geothermal sites and are compared to equilibrium-temperature profiles at these sites. The authors highlight the importance of

\footnotetext{
${ }^{3}$ https://www.eera-geothermal.eu.

4 Added in 2019, after EGW 2018.
} 
accounting for temperature and water saturation when determining accurate heat flow density estimates.

The study by Heap et al. (2019) highlights, from a petrophysical standpoint, the heterogeneous nature of the Muschelkalk, an important Triassic lithostratigraphic unit for Upper Rhine Graben geothermal energy exploitation. They present laboratory data-porosity, P-wave velocity, strength, thermal properties, and Young's modulus-for the Muschelkalk and compare these data with recently acquired data for the Buntsandstein, a Permo-Triassic sequence of sandstones that lies directly beneath the Muschelkalk. The data presented in this study can be used in modelling designed to optimize geothermal energy exploitation in the region.

The role of temperature variations on fracture permeability is explored by Lima et al. (2019) using near-field experiments on granodiorites from the Grimsel Test Site. These flow-through laboratory experiments address the effect of temperature on the hydraulic properties of natural fractures subjected to applied stresses, and quantify changes to fracture surfaces as well as effluent composition. The authors conclude that thermal dilation, mechanical grinding, and pressure dissolution likely control fracture compaction.

Lepillier et al. (2019) couple rock physical data, dense discrete fracture networks, and finite element modelling to assess the dependence of fracture permeability on stress and define conditions for fluid flow through fractures in two geothermal systems located in the Trans-Mexican volcanic belt. Their approach offers a prediction for multiple scenarios of reservoir flow characteristics in these systems, offering new insights that could improve the development of EGS technologies at these sites.

A multidisciplinary approach is used by Duwiquet et al. (2019) to investigate the potential for geothermal exploitation in crustal fault systems, with particular emphasis on the Pontgibaud fault zone in the French Massif Central. This study uses field, laboratory, and X-ray tomography methods to characterize the matrix and fracture contributions to reservoir permeability. These data are then used to inform numerical models that investigate the role of fault dip and permeability on geothermal reservoir potential. This potentially predictive tool can be used to model geothermal targets in large-scale fault systems hosted by basement rocks.

Chen et al. (2019) designed a series of modelling scenarios to simulate and assess the performance of deep borehole exchangers (DBHE) as a function of pipe materials, grout and soil thermal conductivity, geothermal gradient, and groundwater flow. The extended numerical model presented in this study can be used in the design and optimization of DBHE-coupled ground source heat pump systems.

Wang et al. (2019) use a numerical approach to investigate the influencing parameters and uncertainties in the interpretation of borehole logging data. To do this, they simulated different well operation conditions for high-enthalpy wells and create synthetic temperature logs in a newly developed wellbore simulator. The authors provide insights on the key factors influencing well temperature distribution, which can be used to inform the choice of drilling data used to estimate static formation temperature and the design of inverse modelling schemes in future studies.

Vallier et al. (2020) present a new series of 2D and 3D thermo-hydro-mechanical (THM) models that suggest that a contribution of the regional gravity anomalies near geothermal sites in the Upper Rhine Graben-classically attributed to geological features-could be the result of deep, reservoir-scale hydrothermal circulation. Their model 
predictions show that synthetic gravity variations for the region have a wavelength of about $7.5 \mathrm{~km}$, which is consistent with the width of hydrothermal convection cells in the region. The predicted amplitude of these anomalies is small $(\sim 20 \mu \mathrm{Gal})$ and can be resolved by absolute gravimetry and, thus, measurable in the field.

A new statistical, multi-component geothermometer for reservoir temperature estimation is proposed by Ystroem et al. (2020). This new tool requires a significantly reduced geochemical dataset compared to existing approaches and is validated against reservoir temperature measurements in the high-enthalpy Krafla and Reykjanes geothermal systems. This new geothermometer is quick and easy-to-use and provides robust results without the need for sophisticated gas analysis.

Finally, the successful implementation of a binary plant at a geothermal site in Indonesia is presented by Frick et al. (2019). The authors provide technical details and design considerations for the integration of this fully automated binary plant and show that the maximum power capacity of this novel system is $400 \mathrm{~kW}$, with the possibility of attaining $500 \mathrm{~kW}$ in the future.

We invite you to explore these rich contributions in more detail.

\section{Authors' contributions}

ARLK and ML wrote the manuscript. Both authors read and approved the final manuscript.

\section{Funding}

Financial support of the 6th European Geothermal Workshop was provided by the LabEx G-eau-thermie Profonde hosted by the Ecole et Observatoire des Sciences de la Terre (EOST-Strasbourg University/CNRS), the European Energy Research Alliance's Geothermal Joint Programme (EERA Geothermal), and the Université Franco-Allemande (UFA). The scientific committee of the workshop was composed of representatives from the LabEx, EERA, and the Karlsruhe Institute of Technology's Geothermal Chair.

\section{Competing interests}

The authors declare that they have no competing interests.

\section{Author details}

1 Université de Strasbourg, CNRS, IPGS, UMR 7516, 67000 Strasbourg, France. ${ }^{2}$ Geothermal Alliance Bavaria, Munich School of Engineering, Technical University of Munich, Munich, Germany.

Published online: 19 May 2020

\section{References}

Chen C, Shao H, Naumov D, Kong Y, Tu K, Kolditz O. Numerical investigation on the performance, sustainability, and efficiency of the deep borehole heat exchanger system for building heating. Geotherm Energy. 2019;7:18.

Duwiquet H, Arbaret L, Guillou-Frottier L, Heap MJ, Bellanger M. On the geothermal potential of crustal fault zones: a case study from the Pontgibaud area (French Massif Central, France). Geotherm Energy. 2019;7:33.

Frick S, Kranz S, Kupfermann G, Saadat A, Huenges E. Making use of geothermal brine in Indonesia: binary demonstration power plant Lahendong/Pangolombian. Geotherm Energy. 2019;7:30.

Gascuel V, Bédard K, Comeau FA, Raymond J, Malo M. Geothermal resource assessment of remote sedimentary basins with sparse data: lessons learned from Anticosti Island, Canada. Geotherm Energy. 2020;8:3.

Harlé P, Kushnir ARL, Aichholzer C, Heap MJ, Hehn R, Maurer V, Baud P, Richard A, Genter A, Duringer P. Heat flow density estimates in the Upper Rhine Graben using laboratory measurements of thermal conductivity on sedimentary rocks. Geotherm Energy. 2019;7:38.

Heap MJ, Kushnir ARL, Gilg HA, Violay MES, Harlé P, Baud P. Petrophysical properties of the Muschelkalk from the Soultzsous-Forêts geothermal site (France), an important lithostratigraphic unit for geothermal exploitation in the Upper Rhine Graben. Geotherm Energy. 2019;7:27.

Lepillier B, Daniilidis A, Doonechaly Gholizadeh N, Bruna PO, Kummerow J, Bruhn D. A fracture flow permeability and stress dependency simulation applied to multi-reservoirs, multi-production scenarios analysis. Geotherm Energy. 2019;7:24

Lima MG, Vogler D, Querci L, Madonna C, Hattendorf B, Saar MO, Kong XZ. Thermally driven fracture aperture variation in naturally fractured granites. Geotherm Energy. 2019;7:23.

Vallier B, Magnenet V, Schmittbuhl J, Fond C. THM modeling of gravity anomalies related to deep hydrothermal circulation at Soultz-sous-Forêts (France). Geotherm Energy. 2020;8:13. https://doi.org/10.1186/s40517-020-00167-8. 
Wang J, Nitschke F, Gholami Korzani M, Kohl T. Temperature log simulations in high-enthalpy boreholes. Geotherm Energy. 2019;7:32.

Ystroem LH, Nitschke F, Held S, Kohl T. A multicomponent geothermometer for high-temperature basalt settings. Geotherm Energy. 2020;8:2.

\section{Publisher's Note}

Springer Nature remains neutral with regard to jurisdictional claims in published maps and institutional affiliations.

Submit your manuscript to a SpringerOpen ${ }^{\circ}$ journal and benefit from:

- Convenient online submission

- Rigorous peer review

- Open access: articles freely available online

- High visibility within the field

- Retaining the copyright to your article

Submit your next manuscript at $\boldsymbol{\Delta}$ springeropen.com 